\title{
Anti-Rickettsia spp. antibodies in free-ranging and captive capybaras from southern Brazil ${ }^{1}$
}

\begin{abstract}
Fernanda S. Fortes ${ }^{2}$, Leonilda C. Santos ${ }^{3}$, Zalmir S. Cubas ${ }^{4}$, Ivan R. Barros-Filho², Alexander W. Biondo ${ }^{2}$, Iara Silveira ${ }^{5}$, Marcelo B. Labruna ${ }^{5}$ and Marcelo B. Molento ${ }^{2^{*}}$

ABSTRACT.- Fortes F.S., Santos L.C., Cubas Z.S., Barros-Filho I.R., Biondo A.W., Silveira I., Labruna M.B. \& Molento M.B. 2011. Anti-Rickettsia spp. antibodies in free-ranging and captive capybaras from southern Brazil. Pesquisa Veterinária Brasileira 31(11):10141018. Departamento de Medicina Veterinária, Setor de Ciências Agrárias, Universidade Federal do Paraná, Rua dos Funcionários 1540, Juvevê, Curitiba, PR 80035-050, Brazil. E-mail: molento@ufpr.br

Capybaras (Hydrochaeris hydrochaeris) are among the main hosts of Amblyomma spp. ticks, which is able to transmit Rickettsia species to human beings and animals. Since they are often infested with potential vector ticks, capybaras may be used as sentinels for rickettsiosis, such as the Brazilian Spotted Fever. The aim of the present study was to determine the prevalence of antibodies against Rickettsia spp. using the indirect immunofluorescence assay (IFA) in 21 free-ranging and 10 captive animals from the Zoological Park of the 'Bela Vista Biological Sanctuary' (BVBS), Itaipu Binational, Foz do Iguaçu, Southern Brazil. Antigens of six rickettsial species already identified in Brazil (Rickettsia rickettsii, $R$. parkeri, $R$. bellii, $R$. rhipicephali, R. amblyommii and R. felis) were used for IFA. Ticks from each capybara were collected for posterior taxonomic identification. A total of $19(61.3 \%)$ samples reacted to at least one of tested species. Seropositivity was found in 14 (45.2\%), 12 (38.7\%), 5 (16.1\%), 4 (12.9\%), 3 (9.7\%) and 3 (9.7\%) animals for R. rickettsii, R. bellii, R. parkeri, R. amblyommii, $R$. felis and $R$. rhipicephali, respectively. Two captive capybaras presented suggestive titers of $R$. rickettsii infection and one sample showed homologous reaction to $R$. parkeri. Only one free-ranging capybara presented evidence $R$. bellii infection. Ticks collected on capybaras were identified as Amblyomma dubitatum e Amblyomma sp. Results evidenced the rickettsial circulation in the area, suggesting a potential role of capybaras on bacterial life cycle.
\end{abstract}

INDEX TERMS: Rickettsia, spotted fever, serology, capybaras, zoonoses.

RESUMO.- [Anticorpos anti-Rickettsia spp. em capivaras de vida livre e de cativeiro no Sul do Brasil.] As capivaras (Hydrochaeris hydrochaeris) estão entre os prin-

\footnotetext{
${ }^{1}$ Received on May 12, 2011.

Accepted for publication on July 29, 2011.

${ }^{2}$ Departamento de Medicina Veterinária, Setor de Ciências Agrárias, Universidade Federal do Paraná, Rua dos Funcionários 1540, Juvevê, Curitiba, PR 80035-050, Brazil. *Corresponding author: molento@ufpr.br

${ }^{3}$ Laboratório Ambiental, Itaipu Binacional, Rua Teresina 62, Vila C. Nova, Foz do Iguaçu, PR 85856-970, Brazil

${ }^{4}$ Refúgio Biológico Bela Vista, Itaipu Binacional, Rua Teresina 62, Vila C. Nova, Foz do Iguaçu, PR.

${ }^{5}$ College of Veterinary Medicine, Pathobiology and Population Medicine Department, Mississippi State University, P.O. Box 6100, Mississippi State, MS 39762-6100, USA.

${ }^{6}$ Faculdade de Medicina Veterinária, Departamento de Medicina Veterinária Preventiva e Saúde Animal, Universidade de São Paulo, Av. Prof. Dr. Orlando Marques de Paiva 87, Cidade Universitária São Paulo, SP 05508270, Brazil.
}

cipais hospedeiros do carrapato Amblyomma spp., o qual pode transmitir algumas espécies de riquétsias para seres humanos e animais. Como são frequentemente infestadas por carrapatos vetores potenciais, as capivaras podem ser usadas como sentinelas para riquetsioses, como a Febre Maculosa Brasileira. 0 objetivo do presente estudo foi determinar a soroprevalência de Rickettsia spp. por meio da reação de Imunofluorescência Indireta (RIFI) em 21 capivaras de vida livre e 10 capivaras de cativeiro do Zoológico do Refúgio Biológico Bela Vista, Itaipu Binacional, Foz do Iguaçu, Brasil. Antígenos de seis espécies de riquétsias já identificadas no Brasil (Rickettsia rickettsii, R. parke$r i, R$. bellii, $R$. rhipicephali, $R$. amblyommii e $R$. felis) foram utilizados para a RIFI. Carrapatos de cada capivara foram coletados para posterior identificação taxonômica. Um total de $19(61,3 \%)$ amostras reagiu a pelo menos uma das espécies testadas. Foi encontrada soropositividade em 14 
(45,2\%), 12 (38,7\%), 5 (16,1\%), 4 (12,9\%), $3(9,7 \%)$ e 3 $(9,7 \%)$ animais para $R$. rickettsii, $R$. bellii, R. parkeri, $R$. amblyommii, $R$. felis e $R$. rhipicephali, respectivamente. Duas capivaras de cativeiro apresentaram títulos sugestivos de infecção por $R$. rickettsii e uma amostra apresentou reação homóloga frente à $R$. parkeri. Apenas uma capivara de vida livre apresentou evidência de infecção por $R$. bellii. Os carrapatos coletados sobre as capivaras foram identificados como Amblyomma dubitatum e Amblyomma sp. Os resultados evidenciam a circulação de riquétsias na região, sugerindo uma potencial participação da capivara no ciclo de vida desta bactéria.

TERMOS DE INDEXAÇÃO: Rickettsia, febre maculosa, sorologia, capivaras, zoonoses.

\section{INTRODUCTION}

The genus Rickettsia is composed by different species of obligate intracellular bacteria, many of which are the cause of zoonotic diseases in different parts of the world, while others are considered as non pathogenic or of non established pathogenicity for humans (Labruna 2009). At least seven Rickettsia species were reported in Brazil: R. ricketttsii, R. parkeri, R. rhipicephali, R. amblyommii and R. bellii, associated to ticks; and R. felis and R. typhi, which are associated to fleas. The disease caused by $R$. rickettsii is responsible for high lethality rates in humans in Brazil.

Recently recognized as a pathogenic agent with low incidence in Spotted Fever in the United States, and probably in Uruguay as well (Paddock 2005), R. parkeri is also believed to occur in Brazil. Although there are still no reports of human cases due to R. parkeri in Brazil, this agent has been detected in ticks such as Amblyomma triste and A. dubitatum, in São Paulo State (Labruna et al. 2004b, Silveira et al. 2007). Moreover, serological evidence of infection by $R$. parkeri has been found in dogs, horses, opossums (Horta et al. 2007) and in capybaras (Pacheco et al. 2007) of São Paulo State.

Rickettsia felis e R. typhi are responsible for a less severe disease in humans when compared to $R$. rickettsii (Parola et al. 2005), both recently reported in Brazil (Labruna 2009). Other agents, such as $R$. bellii, still remain with unknown pathogenicity for human beings, although the specie has been reported to infect several tick species in Brazil (Labruna et al. 2004a,b, Pinter \& Labruna 2006, Pacheco et al. 2009).

Amblyomma cajennense ticks are considered the main vectors of Brazilian Spotted Fever (BSF) (Guedes et al. 2005) and horses, capybaras and tapirs are included as the main hosts for this tick. Capybaras (Hydrochaeris hydrochaeris) are the primary host for A. dubitatum ticks, which although not yet confirmed as competent vector for $R$. rickettsii, it is suspected to participate in Rickettsia spp. transmission to human (Souza et al. 2009). Capybaras are often infested by potential vector ticks and therefore may be used as a sentinel host to indicate the occurrence of $R i$ ckettsia spp.

Main evidences of BSF in human beings were found in certain areas of Southeastern Brazil where capybaras are abundantly found (Pinter et al. 2008). However, there is lit- tle knowledge on the disease epidemiology in most of the country, which are still considered non endemic or of unknown endemicity. Considering the role of animals as sentinel for BSF, and the increasing population of the species in the area of study, the present work was aimed to evaluate the presence of antibodies anti-Rickettsia spp. in free-ranging and captive capybaras from Bela Vista Biological Sanctuary, Itaipu Binational, Foz do Iguaçu, a three border city (Brazil, Paraguay and Argentina), in Southern Brazil.

\section{MATERIALS AND METHODS}

Area of study. The present study was conducted in Foz do Iguaçu ,city $\left(25^{\circ} 32^{\prime} 45^{\prime \prime} \mathrm{S}, 5^{\circ} 35^{\prime} 07^{\prime \prime} \mathrm{W}\right)$, border of Southern Brazil, Paraguay and Argentina, where the electric power plant Itaipu Binational is located.

Captive capybaras were kept in a $250 \mathrm{~m}^{2}$ fenced area at the Bela Vista Biological Sanctuary (BVBS), located at the Itaipu Binational area and open to visitors and tourists. Free-ranging capybaras living around a nearby lake in the same area were captured by fenced bait traps and released in the same day. Free-ranging capybaras had no direct access to captive animals but only through iron fence.

Animals. A total of 31 capybaras (Hydrochaeris hydrochaeris), 10 maintained in captivity at the BVBS and 21 free-range on Itaipu Binational area were used in the present study. After approval by the Brazilian National Wildlife Institute (IBAMA, protocol 125871 ), rodents were manually restrained and anesthetized with $2 \%$ Xylazine Chloride $(0.5 \mathrm{mg} / \mathrm{kg})$ and $10 \%$ Ketamine Chloride $(7.0$ $\mathrm{mg} / \mathrm{kg}$ ). Blood samples were obtained from femoral vein and placed in tubes without anticoagulant, centrifuged, serum separated and stored at $-70^{\circ} \mathrm{C}$ until testing. During clinical examination and under anesthesia, capybaras were carefully inspected for ticks, which were collected and placed in 70\% alcohol for posterior taxonomic classification as described by Barros-Battesti et al. (2006).

Indirect Immunofluorescence Assay (IFA). Indirect immunofluorescence assay (IFA) was performed through serum samples reaction to VERO cells infected with $R$. rickettsii (strain Taiaçu), R. parkeri (strain AT24), R. bellii (strain Mogi), R. rhipicephali (strain HJ5), R. amblyommii (strain Ac37), and R. felis (strain Pedreira), fixed on microscope slides for immunofluorescence. Reaction of slide antigens with ovine IgG anti-capybara antibodies (Zoonoses Control Center, Sao Paulo, Brazil) marked with fluorescein isothiocyanate was visualized by ultraviolet light microscope. Samples with IFA reaction at dilution $\geq 1: 64$ were considered positive and further tested until 1:1024 dilutions. All samples with titers at least four-times greater for a Rickettsia species when compared to others were considered homologous for the highest titer (Pacheco et al. 2007).

\section{RESULTS}

A total of $19(61.3 \%)$ samples presented a positive reaction to at least one Rickettsia species to the dilution of 1:64 (Table 1). Seropositive samples were found in $14(45.2 \%), 12$ (38.7\%), 5 (16.1\%), 4 (12.9\%), 3 (9.7\%) e 3 (9.7\%) capybaras for $R$. rickettsii, $R$. bellii, $R$. parkeri, $R$. amblyommii, $R$. felis and $R$. rhipicephali, respectively.

Reactivity against $R$. rickettsii, the causative agent of BSF was observed in 6/10 (60.0\%) captive capybaras, higher when compared to $8 / 21$ (38.1\%) free-ranging capybaras. Rickettsia bellii, on the other hand, was similar in both groups, with positive reaction in $4 / 10(40.0 \%)$ captive and $8 / 21(38.1 \%)$ free-ranging capybaras. 
Table 1. Endpoint titers of indirect immunofluorescence assay (IFA) for six Rickettsia species in capybaras (Hydrochaeris hydrochaeris) from Foz do Iguaçu, Paraná state, southern Brazil

\begin{tabular}{|c|c|c|c|c|c|c|c|}
\hline \multirow[t]{2}{*}{ Serum } & \multicolumn{6}{|c|}{ IFA titers for the following antigens } & \multirow[t]{2}{*}{ PAIHR } \\
\hline & R. rickettsii & R.parkeri & R. bellii & R. felis & R. amblyommii & R. rhipicephali & \\
\hline 1 & - & - & 64 & - & - & - & \\
\hline 2 & 256 & 128 & 256 & 128 & 256 & 64 & \\
\hline 3 & 64 & - & 64 & - & - & - & \\
\hline 4 & 128 & 128 & 64 & 64 & 128 & - & \\
\hline 5 & 64 & - & 64 & - & - & - & \\
\hline 8 & - & - & 64 & - & - & - & \\
\hline 11 & - & - & 128 & - & - & - & R. bellii \\
\hline 12 & 64 & - & - & - & - & - & \\
\hline 13 & 64 & - & - & - & - & - & \\
\hline $1 \mathrm{a}$ & - & - & - & - & 128 & 128 & \\
\hline $2 \mathrm{a}$ & 512 & 512 & 256 & 128 & 512 & 512 & \\
\hline $3 a$ & 256 & 128 & - & - & - & - & \\
\hline $2^{*}$ & 256 & - & 128 & - & - & - & \\
\hline $3^{*}$ & 128 & - & 64 & - & - & - & \\
\hline $4^{*}$ & 128 & - & - & - & - & - & R. rickettsii \\
\hline $5^{*}$ & - & - & 64 & - & - & - & \\
\hline $8^{*}$ & 128 & - & - & - & - & - & R. rickettsii \\
\hline $9^{*}$ & 64 & - & - & - & - & - & \\
\hline $10^{*}$ & 64 & 256 & 64 & - & - & - & R. parkeri \\
\hline
\end{tabular}

Table 2. Ticks collected from capybaras (Hydrochaeris hydrochaeris) from Foz do Iguaçu, Paraná state, southern Brazil

\begin{tabular}{|c|c|c|c|c|c|c|c|}
\hline \multirow{3}{*}{ Capybara } & \multicolumn{2}{|c|}{ Origin } & \multicolumn{4}{|c|}{ Ticks } & \multirow[t]{3}{*}{ Total } \\
\hline & \multirow[t]{2}{*}{ Captive } & \multirow[t]{2}{*}{ Free-ranging } & \multicolumn{2}{|c|}{ Amblyomma dubitatum } & \multicolumn{2}{|c|}{ Amblyomma sp. } & \\
\hline & & & Female & Male & Larvae & Nymphs & \\
\hline $1+$ & & $\mathrm{x}$ & 6 & - & - & 1 & 7 \\
\hline $2+$ & & $\mathrm{x}$ & 12 & 5 & - & - & 17 \\
\hline $3^{+}$ & & $\mathrm{x}$ & 17 & 4 & - & 1 & 22 \\
\hline $4^{\dagger}$ & & $\mathrm{x}$ & 6 & 1 & - & 3 & 10 \\
\hline $5^{+}$ & & $\mathrm{x}$ & 10 & 2 & - & 1 & 13 \\
\hline 6 & $\mathrm{x}$ & & 2 & 3 & - & 6 & 11 \\
\hline 7 & $\mathrm{x}$ & & 2 & 6 & - & 1 & 9 \\
\hline $8^{+}$ & $\mathrm{x}$ & & 3 & 3 & - & - & 6 \\
\hline 9 & & $\mathrm{x}$ & 9 & 1 & - & - & 10 \\
\hline 10 & $\mathrm{x}$ & & 3 & 3 & - & 1 & 7 \\
\hline 11 & & $\mathrm{x}$ & 5 & 1 & - & 2 & 8 \\
\hline $12^{\dagger}$ & & $\mathrm{x}$ & - & 8 & - & 1 & 9 \\
\hline $13^{+}$ & & $\mathrm{x}$ & 2 & 3 & - & 1 & 6 \\
\hline 14 & & $\mathrm{x}$ & 6 & - & - & - & 6 \\
\hline 15 & & $\mathrm{x}$ & 3 & 5 & - & 1 & 9 \\
\hline 16 & & & 5 & 1 & - & 2 & 8 \\
\hline $1 \mathrm{a}^{\dagger}$ & & $\mathrm{x}$ & 1 & - & 6 & 37 & 44 \\
\hline $2 \mathrm{a}^{+}$ & & $\mathrm{x}$ & - & 1 & - & 22 & 23 \\
\hline $3 a^{\dagger}$ & & $\mathrm{x}$ & - & - & - & 21 & 21 \\
\hline \multirow[t]{2}{*}{$4 a$} & & $\mathrm{x}$ & - & 1 & - & 13 & 14 \\
\hline & & & & & & & 260 \\
\hline
\end{tabular}

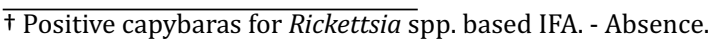

Serological evidence of Rickettsia infection was obtained for four capybaras: two captive capybaras presented suggestive titers for $R$. rickettsii infection; one captive capybara for R. parkeri; and one free range capybara presented evidence of infection for $R$. bellii.

A total of 260 ticks, including 140 adults, 114 nymphs and 6 larvae, were collected during capybaras sampling. All adults were identified as Amblyomma dubitatum ( 92 females and 48 males) (Table 2).

\section{DISCUSSION}

Overpopulation of capybaras in certain endemic areas of BSF has been accompanied by a high environmental tick burden. Moreover, capybaras have been reportedly shown to play a role as amplifier hosts for Rickettsia rickettsii in Amblyoma cajennense ticks, increasing the risk for spreading the disease (Souza et al. 2009).

IFA is the "gold standard" method for the diagnosis of rickettsiosis in humans and animals and is used as a reference method in most laboratories (La Scola \& Raoult 1997). Cross-reactivity among rickettsiae of different groups can occur (Labruna et al. 2004b, Pacheco et al. 2007), and sera showing at least 4-fold higher titer for a particular Rickettsia species was considered homologous to the Rickettsia species with the highest titer or to a very closely related genotype (Horta et al. 2004, Pacheco et al. 2007). 
The finding of such a large number of positive capybaras $(61.3 \%)$ are very similar to a previous study with $54 / 73$ (74\%) positive animals from a non-endemic area of São Paulo State (Pacheco et al. 2007). A serological study for $R$. rickettsii in 177 capybaras living in areas where BSF was previously detected in humans has showed a low prevalence in one out of five $(7.3 \%)$, and a similar trend in the other areas (37.5\%, 41.6\%, 53.3\% and 59.4\%) (Souza et al. 2008). The authors determined that the serums from 34 capybaras from 3 different areas with no previous report of BSF were tested negative for IFA (Souza et al. 2008). Therefore, the highly serological evidence of Rickettsia infection found in the present study suggests the circulation of Rickettsia bacteria in capybaras of the three-country border area.

Serological survey in wildlife animals (capybaras and opossums) for Rickettsia species in Brazil have been conducted predominantly in São Paulo State (Horta et al. 2007, Pacheco et al. 2007). In 73 capybaras from six areas of São Paulo State, where BSF has never been reported, were found seropositivity of $26.0,34.2$ e $68.5 \%$ for $R$. rickettsii, $R$. parkeri and $R$. bellii, respectively. Differently from the present study where the authors found higher prevalence for $R$. rickettsii (45.2\%), followed by $R$. bellii (38.7\%) and $R$. parkeri $(16.1 \%)$.

The present data may indicate the risk for potential human contact with $R$. rickettsii and $R$. parkeri. Evidence of infection by $R$. rickettsii was not expected, since the region is considered free for the disease, with no circulating agent. Another factor of complexity is that the rickettsial infection may have been underestimated on humans' diagnosis since no reports have been historically found in either humans or animals. Since Foz do Iguaçu is a Three-Border city, evidence of infection may be extended to nearby borders of Paraguay and Argentina, making the disease an international zoonotic threat.

A previous survey in the Northern area of Paraná State has found $7 / 34(20.6 \%)$ of seropositive park employees and none of 775 A. dubitatum of the ticks surveyed (Toledo et al. 2008, Toledo 2008). However, negative Rickettsia results from molecular studies on ticks would not rule out the risk of human infection. Although the pathogenic potential of both $R$. rickettsii and $R$. parkeri causing human infection have been described (Pacheco et al. 2007), the susceptibility of $R$. bellii agent is still unknown and should be further investigated.

All adult ticks obtained during the sampling in the present study were identified as $A$. dubitatum ticks. Pacheco et al. (2007) reported that the majority of the capybaras from 6 cities of São Paulo State with no previous report of BSF were infested with $A$. dubitatum ticks. In this study, serological evidence of infection by $R$. parkeri has been found in only one city, and by $R$. bellii in four other cities. More recently, $R$. bellii was the only one Rickettsia species found infecting A. dubitatum ticks in São Paulo State (Pacheco et al. 2009).

The present study reports for the first time the serological evidence of Rickettsia spp. in free-ranging and captive capybaras of Foz do Iguaçu. Since both capybara populations are in close contact with each other and humans, it is advisable to start a rickettsia monitoring program to fully establish the epidemiology of BSF in the area.

Acknowledgements.- Funding for Dr. Fernanda Silva Fortesx was provided by the Conselho Nacional de Desenvolvimento Científico e Tecnológico (CNPq). We kindly thank the personal of the Itaipu, Foz do Iguaçu city, for all sampling support for the study.

\section{REFERENCES}

Barros-Battesti D.M., Arzua M. \& Bechara G.H. 2006. Carrapatos de importância médico-veterinária da região Neotropical: um guia ilustrado para identificação de espécies. Vox/ICTTD-3/Butantã, São Paulo. 223p.

Estrada D.A., Schumaker T.T.S., Souza C.E., Rodrigues Neto E.J. \& Linhares A.X. 2006. Detecção de riquétsias em carrapatos do gênero Amblyomma (Acari: Ixodidae) coletados em parque urbano do município de Campinas, SP. Revta. Soc. Bras. Med. Trop. 39:68-71.

Guedes E., Leite R.C., Prata M.C., Pacheco R.C., Walker D.H. \& Labruna M.B. 2005. Detection of Rickettsia rickettsii in the tick Amblyomma cajennense in a new Brazilian spotted fever-endemic area in the state of Minas Gerais. Mem. Inst. Oswaldo Cruz 100:841-845.

Horta M.C., Labruna M.B., Pinter A., Linardi P.M. \& Schumaker T.T.S. 2007. Rickettsia infection in five areas of the State of São Paulo, Brazil. Mem. Inst. Oswaldo Cruz 102:793-801.

Horta M.C., Labruna M.B., Sangioni L.A., Vianna M.C., Gennari S.M., Galvão M.A.M., Mafra C.L., Vidotto O., Schumaker T.T.S. \& Walker D.H. 2004. Prevalence of antibodies to Spotted Fever Group Rickettsiae in humans and domestic animals in a Brazilian Spotted Fever-Endemic area in the State of São Paulo, Brazil: Serologic evidence for infection by Rickettsia rickettsii and another spotted fever group Rickettsia. Am. J. Trop. Med. Hyg. 71:93-97.

Labruna M.B. 2009. Ecology of Rickettsia in South America. Ann. N. Y. Acad. Sci. 1166:156-166.

Labruna M.B., Pacheco R.C., Richtzenhain L.J. \& Szabó M.P.J. 2007. Isolation of Rickettsia rhipicephali and Rickettsia bellii from the Haemaphysalis juxtakochi Ticks in the State of São Paulo, Brazil. Appl. Environ. Microbiol. 73:869-873.

Labruna M.B., Whitworth T., Bouyer D.H., McBride J.W., Camargo L.M.A., Camargo E.P., Popov V. \& Walker D.H. 2004a. Rickettsia bellii and Rickettsia amblyommii in Amblyomma Ticks from the State of Rondônia, Western Amazon, Brazil. J. Med. Entomol. 41:1073-1081.

Labruna M.B., Whitworth T., Horta M.C., Bouyer D.H., McBride J.W., Pinter A., Popov V., Gennari S.M. \& Walker D.H. 2004b. Rickettsia species infecting Amblyomma cooperi ticks from an area in the State of São Paulo, Brazil, where Brazilian spotted fever is endemic. J. Clin. Microbiol. 42:90-98.

La Scola B. \& Raoult D. 1997. Laboratory diagnosis of Rickettsioses: current approaches to diagnosis of old and new Rickettsial diseases. J. Clin. Microbiol. 35:2715-2727.

Lemos E.R.S., Melles H.H.B., Colombo S., Machado R.D., Coura J.R., Guimarães M.A.A., Sanseverino S.R. \& Moura A. 1996. Primary isolation of spotted fever in the group rickettsiae from Amblyomma cooperi collected from $\mathrm{Hy}$ drochaeris hydrochaeris in Brazil. Mem. Inst. Oswaldo Cruz 91:273-275.

Pacheco R.C., Horta M.C., Moraes-Filho J., Ataliba A.A., Pinter A. \& Labruna M.B. 2007. Rickettsial infection in capybaras (Hydrochoerus hydrochaeris) from São Paulo, Brazil: serological evidence for infection by Rickettsia bellii and Rickettsia parkeri. Biomédica 27:364-371.

Pacheco R.C., Horta M.C., Pinter A., Moraes-Filho J., Martins T.F., Nardi M.S., Souza S.S.A., Souza C.E., Szabó M.P.J., Richtzenhain L.J. \& Labruna M.B. 2009. Pesquisa de Rickettsia spp em carrapatos Amblyomma cajennense e Amblyomma dubitatum no Estado de São Paulo. Revta Soc. Bras. Med. Trop. 42:351-353.

Paddock C.D. 2005. Rickettsia parkeri as a paradigm for multiple causes of tick-borne spotted fever in the western hemisphere. Ann. N. Y. Acad. Sci. 1063:315-326.

Parola P., Paddock C.D. \& Raoult D. 2005. Tick-borne rickettsioses around the world: emerging diseases challenging old concepts. Clin. Microbiol. Rev. 18:719-756. 
Pinter A., Horta M.C., Pacheco R.C., Moraes-Filho J. \& Labruna M.B. 2008. Serosurvey of Rickettsia spp. in dogs and humans from an endemic area for Brazilian spotted fever in the State of São Paulo, Brazil. Cad. Saúde Pública 24:247-252.

Pinter A. \& Labruna M.B. 2006. Isolation of Rickettsia rickettsii and Rickettsia bellii in cell culture from the tick Amblyomma aureolatum in Brazil. Ann. N. Y. Acad. Sci. 1078:523-529.

Silveira I., Pacheco R.C., Szabó M.P.J., Ramos H.G.C. \& Labruna M.B. 2007. Rickettsia parkeri in Brazil. Emerg. Infect. Dis. 13:1111-1113.

Souza C.E., Moraes-Filho J., Ogrzewalska M., Uchoa F.C., Horta M.C., Souza S.S., Borba R.C. \& Labruna M.B. 2009. Experimental infection of capybaras Hydrochoerus hydrochaeris by Rickettsia rickettsii and evaluation of the transmission of the infection to ticks Amblyomma cajennense. Vet. Parasitol. 161:116-121.
Souza C.E., Souza S.S.L., Lima V.L.C., Calic S.B., Camargo M.C.G.O., Savani E.S.M.M., D’auria S.R.N., Linhares A.X. \& Yoshinari N.H. 2008. Serological identification of Rickettsia spp from the spotted fever group in capybaras in the region of Campinas-SP, Brazil. Ciência Rural 38:16941699.

Toledo R.S. 2008. Aspectos epidemiológicos de rickettsias do grupo da febre maculosa em humanos, cães, eqüinos e de Rickettsia spp em carrapatos em Londrina, PR. Dissertação de Mestrado em Ciência Animal, Setor de Ciências Agrárias, Universidade Estadual de Londrina, Londrina, PR. 79p.

Toledo R.S., Tamekuni K., Haydu V.B. \& Vidotto O. 2008. Dinâmica sazonal de carrapatos do gênero Amblyomma (Acari: Ixodidae) em um parque urbano da cidade de Londrina, PR. Revta Bras. Parasitol. Vet. 17:50-54. 